\title{
Comparative Analysis About Clinical Manifestation and Prognostic Factors of Thyroid Follicular and Hurthle Cell Carcinoma
}

\author{
Jung Jun Kim ${ }^{1}$, Brian Kim ${ }^{1}$, Ik Joon Choi ${ }^{1}$, Byeong-Cheol Lee ${ }^{1}$, \\ Jung Min Ahn ${ }^{1}$, Joon Seog Kong ${ }^{2}$, and Myung-Chul Lee ${ }^{1}$ (D) \\ Departments of ${ }^{1}$ Otorhinolaryngology-Head and Neck Surgery and ${ }^{2}$ Pathology, Korea Cancer Center Hospital, \\ Korea Institute of Radiological and Medical Science, Seoul, Korea
}

\section{갑상선 여포암과 휘틀세포암의 임상양상과 예후인자에 대한 비교 연구}

김정준 ${ }^{1} \cdot$ 김브라이언 $^{1} \cdot$ 최익준 ${ }^{1}$ 이병철 ${ }^{1}$ 안정민 ${ }^{1} \cdot$ 공준석 $^{2} \cdot$ 이명철 ${ }^{1}$

한국원자력의학원 원자력병원 ${ }^{1}$ 이비인후-두경부외과, ${ }^{2}$ 병리과

Received July 7, 2021

Revised August 23, 2021

Accepted September 13, 2021

Address for correspondence

Myung-Chul Lee, MD, PhD

Department of Otorhinolaryngology-

Head and Neck Surgery,

Korea Cancer Center Hospital,

Korea Institute of Radiological

and Medical Science,

75 Nowon-ro, Nowon-gu,

Seoul 01812, Korea

Tel $+82-2-970-2173$

Fax $+82-2-970-2450$

E-mail entdok@gmail.com
Background and Objectives Follicular thyroid carcinoma (FTC) is the second common thyroid cancer which comprises about $10 \%$ of differentiated thyroid carcinoma. Hurthle cell carcinoma (HCC) is a relatively rare disease that has been classified as a subtype of FTC. However, there have been insufficient reports about these two similar thyroid cancers in South Korea due to low incidences. This study aims to present clinical features and evaluate prognostic factors of FTC and HCC.

Subjects and Method We reviewed data of $189 \mathrm{FTC}$ and $12 \mathrm{HCC}$ patients who underwent surgery in our center from January 2000 to December 2020. Variables such as clinical characteristics, surgical method, pathologic result, post-operative treatment, survival rate and prognostic factors were included in our study.

Results As for age, $67.2 \%$ of patients in FTC group and $33.3 \%$ of patients in HCC group were older than 55 years-old ( $p=0.017$ ). The average tumor sizes of FTC and HCC were 2.98 and $3.1 \mathrm{~cm}$, respectively. The 10-year overall survival rates of FTC and HCC were $96.5 \%$ and $100 \%$, respectively. The 10 -year disease free survival rates of FTC and HCC were $89.1 \%$ and $91.7 \%$, respectively. Subclassification (widely invasive: $p=0.036$ ) and initial distant metastasis $(p<0.001)$ were significant prognostic factors in FTC.

Conclusion This study will be helpful for diagnosis and treatment of FTC and HCC, which are relatively rare.

Korean J Otorhinolaryngol-Head Neck Surg 2021;64(12):906-13

\section{서 론}

갑상선 여포암(follicular thyroid carcinoma)은 전체 갑상 선암 중 대략 $10 \%$ 정도를 차지하는 2 번째로 흔한 암이며,

This is an Open Access article distributed under the terms of the Creative Commons Attribution Non-Commercial License (https://creativecommons.org/licenses/by-nc/4.0) which permits unrestricted non-commercial use, distribution, and reproduction in any medium, provided the original work is properly cited.
40-60대의 중년 여성에게 호발한다.1) 여포암은 가장 흔한 유 두암과 같이 분화가 좋은 암으로 분류되나, 유두암과는 다르 게 수술 전 세침흡인검사를 통하여 진단할 수 없으며 림프절 보다는 혈행성 전이를 하고, $10 \%$ 정도에서 뼈와 폐 등으로 전신 전이를 한다. ${ }^{1,2}$

휘틀세포(Hurthle cell)는 풍부한 호산성 과립 세포질을 가 진 크기가 큰 다각형의 세포로, 휘틀세포암은 이러한 휘틀세 
포가 종양 세포의 $75 \%$ 이상을 차지하며 병리 검사상 피막이 나 혈관 침습이 있으면 진단할 수 있다(Fig. 1).,4) 휘틀세포암 은 2017 세계보건기구(World Health Organization, WHO)의 새 분류법이 발표되기 전까지 여포암의 아형으로 분류되어 왔으며, 높은 림프절 및 원격전이 경향, 늦은 재발(late recurrence), 방사성 요오드 치료에 낮은 반응성 등을 보여 다른 분화 갑상선보다 조금 더 공격적인 성향을 띄는 것으로 알려 져 왔다. ${ }^{5,6)}$ 하지만 최근 연구들에서는 휘틀세포암이 이전에 알려졌던 것 만큼 예후가 나쁘지 않다고 보고되고 있다.

우리나라에서는 요오드 섭취가 풍부한 지역적 특성 때문 에 여포암의 발생이 드물어 보고가 많지 않고, 휘틀세포암은 발생 빈도가 더욱 드물어 한 기관에서 여포암과 비교 연구한 예는 이전까지는 없었다.

이에 저자들은 본원에서 치료한 여포암과 휘틀세포암 환자 들의 임상양상과 예후인자에 대한 비교 분석을 시행해 보고 자 하였다.

\section{대상 및 방법}

2000년 1월부터 2020년 12월까지 한국원자력의학원 원자 력병원에서 수술적 치료를 받은 갑상선 여포암 환자 189예와 휘틀세포암 12예를 대상으로 의무기록을 통한 후향적 조사 를 시행하였다. 연령 및 성별, 내원 시 주 증상 및 전신 전이 여부, 수술 전 세침흡인검사 결과, 수술 방법, 병리학적 특징, 수술 후 방사성 요오드 치료 여부, 재발 여부, 마지막 추적 관 찰 시 상태를 확인하였다.

갑상선 여포암과 휘틀세포암 모두 수술 전 검사로 초음파, 세침흡인검사, 컴퓨터단층촬영, 갑상선 기능 검사 등을 시행
하였다. 세침흡인검사 및 수술 중 동결 절편 검사로는 양성과 악성을 구분할 수 없으므로 기본적으로 진단적 갑상선엽절 제술을 시행하였다. 다만 내원 시 원격전이가 있거나, 갑상선 양측의 다발성 종괴가 있거나, 종괴의 크기가 크거나, 수술 중 소견으로 갑상선전절제술이 필요하다고 판단된 경우에는 1 차 치료로 갑상선전절제술을 시행하였다. 수술 후 병리 조직 검사를 토대로 종양의 크기, 다발성 및 양측성, 혈관 침습 소 견 유무, 주변 구조물 침범 여부 등을 확인하였다. 대상군은 $2017 \mathrm{WHO}$ 분류를 참고하여 최종 병리 검사상 피막 침범 정 도에 따라 미세 침습형(minimally invasive), 피막 형성형 혈 관 침습형(encapsulated angioinvasive), 광범위 침습형(widely invasive)으로 분류하였다. ${ }^{3)}$

최종 병리 검사에서 악성으로 확인되면 예후인자들을 고려 하여 추가 수술 여부 및 방사성 동위원소 치료를 결정하였다.

환자들은 수술 후 갑상선 초음파, 경부 및 흥부 컴퓨터단층 촬영(CT), 뼈 스캔 등의 영상학적 검사와 혈청 티로글로불린 및 안티티로글로불린 항체 수치 등의 혈액학적 검사를 통하 여 추적 관찰 및 재발 여부를 확인하였다. 마지막 추적 관찰 에서 재발의 증거가 없는 경우를 무병생존으로, 국소 재발이 나 원격전이의 증거가 있거나 의심되는 경우를 유병생존으로, 재발이나 원격전이, 혹은 그로 인한 합병증 등으로 환자가 사 망한 경우를 질병으로 인한 사망으로 분류하였다.

통계학적 분석은 SPSS 프로그램(Version 23.0; IBM Corp, Armonk, NY, USA)을 이용하였다. 두 군 간의 임상 병리적 특징에 대한 비교는 범주형 자료인 경우 Fisher's exact test를 사용하였고, 연속형 자료인 경우 휘틀세포암의 증례 수가 12건 으로 적고 정규성 검정이 어려운 관계로 비모수적인 방법인 Mann-Whitnney test를 이용하였다. 추적 기간 동안의 전체
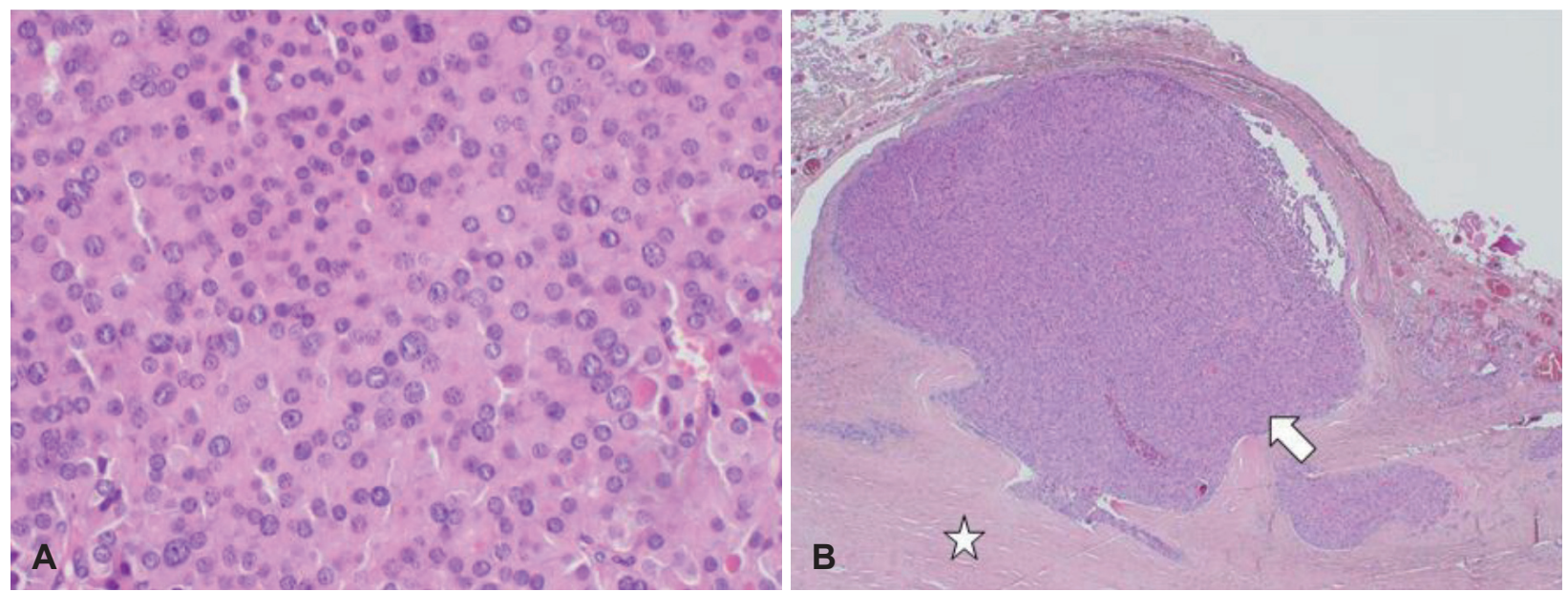

Fig. 1. Microscopic pictures of Hurthle cells (A) and capsular invasion in Hurthle cell carcinoma (B). Hurthle cells are large polygonal cells derived from thyroid follicular epithelium, which contain abundant granular cytoplasm. The cells show solid and trabecular growth pattern (A: H\&E stain, $\times 400)$. Tumor cells (arrow) are invading through the fibrous capsule (star) (B: H\&E stain, $\times 40)$. H\&E, hematoxylin and eosin. 
생존율 및 무병 생존율은 Kaplan-Meier 방법을 사용하였다. 무병 생존율의 예후 인자 분석을 위하여 log-rank법을 이용 하여 단변량 분석을 시행하였으며 그 중 유의하다고 판정된 예후인자들을 다시 Cox regression법을 이용하여 다변량 분 석으로 검증하였다. 본 연구는 본원의 기관생명윤리위원회 심 의를 통과하였다(IRB No. 2021-03-010).

Table 1. Comparison of clinicopathologic characteristics between FTC and HCC

\begin{tabular}{|c|c|c|c|}
\hline Characteristics & $\begin{array}{c}\text { FTC } \\
(n=189)\end{array}$ & $\begin{array}{l}\mathrm{HCC} \\
(n=12)\end{array}$ & $p$-value \\
\hline Age (years) & & & 0.017 \\
\hline$\geq 55$ & $127(67.2)$ & $4(33.3)$ & \\
\hline$<55$ & $62(32.8)$ & $8(66.7)$ & \\
\hline Sex & & & 0.959 \\
\hline Male & $46(24.3)$ & $3(25.0)$ & \\
\hline Female & $143(75.7)$ & $9(75.0)$ & \\
\hline Chief complaints & & & 0.929 \\
\hline Neck mass & $117(61.9)$ & $7(58.3)$ & \\
\hline $\begin{array}{l}\text { Abnormal radiologic finding } \\
\text { of thyroid gland }\end{array}$ & $61(32.3)$ & $4(33.3)$ & \\
\hline Mass in other site than neck & $11(5.8)$ & $1(8.3)$ & \\
\hline Tumor size $(\mathrm{cm})$ & & & 0.456 \\
\hline$\geq 4$ & $45(23.8)$ & $4(33.3)$ & \\
\hline$<4$ & $144(76.2)$ & $8(66.7)$ & \\
\hline Multifocality & & & 0.348 \\
\hline Yes & $13(6.9)$ & $0(0)$ & \\
\hline No & $176(93.1)$ & $12(100.0)$ & \\
\hline Bilaterality & & & 0.568 \\
\hline Yes & $5(2.6)$ & $0(0)$ & \\
\hline No & $184(97.4)$ & $12(100.0)$ & \\
\hline Angioinvasion & & & 0.663 \\
\hline Yes & $52(27.5)$ & $4(33.3)$ & \\
\hline No & $137(72.5)$ & $8(66.7)$ & \\
\hline Invasion to adjacent structure & & & 0.414 \\
\hline Yes & $10(5.3)$ & $0(0)$ & \\
\hline No & $179(94.7)$ & $12(100.0)$ & \\
\hline Subclassification & & & 0.916 \\
\hline Minimally invasive & $120(63.5)$ & $8(66.7)$ & \\
\hline Encapsulated angioinvasive & $39(20.6)$ & $2(16.7)$ & \\
\hline Widely invasive & $30(15.9)$ & $2(16.7)$ & \\
\hline Initial distant metastasis & & & 0.891 \\
\hline Yes & $16(8.5)$ & $1(8.3)$ & \\
\hline No & $173(91.5)$ & $11(91.7)$ & \\
\hline \multirow[t]{2}{*}{ Follow-up period (months) } & 104.1 & 82.6 & 0.247 \\
\hline & $(1-459)$ & $(8-233)$ & \\
\hline
\end{tabular}

Data are presented as $\mathrm{n}(\%)$. FTC, follicular thyroid carcinoma; HCC, Hurthle cell carcinoma

\section{결 과}

갑상선 여포암 환자의 평균 연령은 60.68 (18-97)세였으며, 남녀 비는 46:143이었다. 휘틀세포암의 경우 평균 연령은 50.8 (36-71)세였으며, 남녀 비는 3:9였다. 두 군 간의 연령 비교는 통계적으로 유의한 차이를 보였다( $p=0.017)$. 주 증상은 여포 암의 경우 경부 종괴 117예(61.9\%), 갑상선의 영상학적 이상을 보인 경우 61예(32.3\%), 경부 이외 부분(골반, 견갑골, 척추 등) 의 종괴가 11 예(5.8\%)였으며, 휘틀세포암의 경우 경부 종괴인 경우가 7예(58.3\%), 갑상선의 영상학적 이상을 보인 경우가 4예(33.3\%), 원격전이(전완부 종괴)의 경우가 1예(8.3\%)였다 (Table 1).

수술 전 갑상선 결절의 세침흡인검사 결과는 여포암의 경 우 양성(선종성 갑상선종, 하시모토 갑상선염 등) 27예(14.3\%), 여포상 종양(follicular neoplasm) 104예(55.0\%), 미확정 비정 형 세포(atypia of undetermined significance) 51예(27.0\%), 악성 및 악성 의심 7예(3.7\%)였으며, 휘틀세포암의 경우 휘틀 세포 종양(Hurthle cell neoplasm) 6예(50.0\%), 여포상 종양 4예(33.3\%), 여포상 종양 의심(suspicious for follicular neoplasm) 1예(8.3\%), 휘틀세포 특성의 미확정 비정형 세포(atypia of undetermined significance with Hurthle cell features) 1예(8.3\%)였다(Table 2).

여포암 환자에서 엽절제술만 시행한 경우는 58예(30.7\%)였 으며, 갑상선전절제술을 시행한 경우는 총 130예(68.8\%)였다. 갑상선전절제술로 분류한 예 중 처음부터 갑상선전절제술을 시행한 경우는 총 48예(25.4\%), 엽절제술 후 완결절제술을 시 행한 경우는 82예(43.4\%)였다. 1 예(0.5\%)에서는 첫 수술로 갑 상선전절제술과 측경부 청소술을 같이 시행하였다. 휘틀세포 암 환자의 경우 엽절제술만 시행한 경우는 5예(41.7\%)였으며, 갑상선전절제술을 시행한 경우는 6예(50.0\%)였다. 갑상선전

Table 2. FNA result of FTC and HCC

\begin{tabular}{lc}
\hline \multicolumn{1}{c}{ FNA results } & Value \\
\hline FTC $(\mathrm{n}=189)$ & $27(14.3)$ \\
Benign & $104(55.0)$ \\
Follicular neoplasm & $51(27.0)$ \\
Atypia of undetermined significance & $7(3.7)$ \\
Suspicious malignancy \& malignancy & \\
HCC $(\mathrm{n}=12)$ & $6(50.0)$ \\
Hurthle cell neoplasm & $4(33.3)$ \\
Follicular neoplasm & $1(8.3)$ \\
Suspicious for follicular neoplasm & $1(8.3)$ \\
Atypia of undetermined significance & \\
$\quad$ with Hurthle cell features &
\end{tabular}

Data are presented as $\mathrm{n}$ (\%). FNA, fine needle aspiration; FTC, follicular thyroid carcinoma; HCC, Hurthle cell carcinoma 
절제술로 분류한 예 중 처음부터 갑상선전절제술을 시행한 경우는 3예(25.0\%), 엽절제술 후 완결 절제술을 시행한 경우 는 3예(25.0\%)였다. 1예(8.3\%)에서는 첫 수술로 갑상선전절제 술과 측경부 청소술을 같이 시행하였다. 이후 여포암 환자 중 126예(66.7\%)에서, 휘틀세포암 환자 중 7예(58.3\%)에서 방사 성 요오드 치료를 시행하였다(Table 3).

수술 후 최종 조직 병리 검사상 여포암의 크기는 평균 2.98 (0.6-9.0) $\mathrm{cm}$ 였다. 다발성 및 양측성은 각각 13 (6.9\%)예, 5예 (2.6\%)에서 확인되었으며 52예(27.5\%)에서 혈관 침습이 확인 되었다. 병리학적 분류로는 미세 침습형이 120예(63.5\%), 피 막 형성형 혈관 침습형이 39예(20.6\%), 광범위 침습형이 30예 (15.9\%)였다. 갑상선 주변 구조물을 침범한 경우는 10예(5.3\%) 였다. 휘틀세포암의 경우 크기는 평균 $3.1(0.9-8.0) \mathrm{cm}$ 였고, 12예 모두에서 다발성 및 양측성은 확인되지 않았다. 4예 (33.3\%)에서 혈관 침습을 확인할 수 있었다. 병리학적 분류로

Table 3. Treatment of FTC and HCC

\begin{tabular}{lccc}
\hline \multicolumn{1}{c}{ Treatment } & $\begin{array}{c}\text { FTC } \\
(\mathrm{n}=189)\end{array}$ & $\begin{array}{c}\mathrm{HCC} \\
(\mathrm{n}=12)\end{array}$ & p-value \\
\hline $\begin{array}{l}\text { Extent of surgery } \\
\text { Lobectomy }\end{array}$ & $58(30.7)$ & $5(41.7)$ & 0.019 \\
$\quad$ Total thyroidectomy & $130(68.8)$ & $6(50.0)$ & \\
$\begin{array}{l}\text { Total thyroidectomy } \\
\quad \text { lateral neck dissection }\end{array}$ & $1(0.5)$ & $1(8.3)$ & \\
$\begin{array}{l}\text { Radioactive iodine therapy } \\
\text { Yes }\end{array}$ & $126(66.7)$ & $7(58.3)$ & \\
No & $63(33.3)$ & $5(41.7)$ & \\
\hline
\end{tabular}

Data are presented as $\mathrm{n}$ (\%). FTC, follicular thyroid carcinoma; HCC, Hurthle cell carcinoma
는 미세 침습형이 8예(66.7\%), 피막 형성형 혈관 침습형(encapsulated angioinvasive)이 2예(16.7\%), 광범위 침습형이 2예 (16.7\%)였다. 갑상선 주변 구조물을 침습한 경우는 없었다 (Table 1).

측경부 청소술을 같이 시행한 각각의 1 예 중, 여포암의 경 우에서는 중심경부림프절(2/7) 및 측경부(level $2 \& 3,5 / 6)$ 의 전이를 보였으며, 휘틀세포암의 경우에서도 측경부의 전이 (level 4, 1/7)가 확인되었다.

여포암과 휘틀세포암의 병리적 특징을 비교하였을 때, 종 괴의 크기, 다발성, 양측성, 혈관 침습 여부, 주변 구조물 침범 여부, 피막 침범 정도, 최초 원격전이 등이 차이가 없었다. 평 균 추적 기간은 여포암의 경우 104.1 (1-459)개월이었고, 추적 기간 동안 재발을 보인 경우는 8예였다. 재발한 경우는 병리 학적 분류상 미세 침습형 3예, 피막 형성형 혈관 침습형 1 예, 광범위 침습형 4예였는데, 두개골, 척추, 견갑골, 대퇴골, 폐로 의 원격전이 형태로 재발을 보였다. 내원 시 최초 원격전이가 있었던 경우는 16예로 미세 침습형 2예, 피막 형성형 혈관 침 습형 4예, 광범위 침습형 10예였으며, 척추, 견갑골, 대퇴골, 흉골, 골반골, 폐로의 원격전이를 보였다. 추적 기간 동안 질 병 관련 사망은 6예였고, 10년 전체 생존율 및 무병 생존율은 각각 $96.5 \%, 89.1 \%$ 였다. 휘틀세포암의 경우 평균 추적 기간은 82.6 (8-233)개월이었고, 추적 기간 동안 재발한 경우는 없었 으며, 내원 시 최초 원격전이가 있었던 경우는 1 예였다. 추적 기간 동안 최초 원격전이를 보였던 1예만이 질병으로 인하여 사망하였고, 10년 전체 생존율 및 무병 생존율은 각각 $100 \%$, $91.7 \%$ 였다.

Table 4. Comparison of prognostic factors for 10-year DFS of FTC and HCC

\begin{tabular}{|c|c|c|c|c|}
\hline Variables & FTC $(n=189)$ & $p$-value & $\operatorname{HCC}(n=12)$ & $p$-value \\
\hline Size $(\mathrm{cm})$ & & 0.371 & & N/A \\
\hline$\geq 4$ & $45(82.2)$ & & $4(100)$ & \\
\hline$<4$ & $144(91.3)$ & & $8(87.5)$ & \\
\hline Angioinvasion & & 0.338 & & N/A \\
\hline Yes & $52(77.6)$ & & $4(75.0)$ & \\
\hline No & $137(93.4)$ & & $8(100)$ & \\
\hline Invasion to adjacent structure & & 0.350 & & N/A \\
\hline Yes & $10(50.0)$ & & $0(N / A)$ & \\
\hline No & $179(91.3)$ & & $12(91.7)$ & \\
\hline Subclassification & & & & N/A \\
\hline Minimally invasive & $120(98.3)$ & & $8(100)$ & \\
\hline Encapsulated angioinvasive & $39(87.0)$ & 0.054 & $2(100)$ & \\
\hline Widely invasive & $30(54.5)$ & 0.036 & $2(50.0)$ & \\
\hline Initial distant metastasis & & $<0.001$ & & N/A \\
\hline Yes & $18(6.3)$ & & $1(0)$ & \\
\hline No & $171(96.8)$ & & $11(100)$ & \\
\hline
\end{tabular}

Data are presented as n (10-year DFS, \%). FTC, follicular thyroid carcinoma; HCC, Hurthle cell carcinoma; DFS, disease free survival; N/A, not available 
여포암에서 단변량 분석을 시행하였을 때 10 년 무병 생존 율에 유의미한 인자는 종양의 크기 $(\geq 4 \mathrm{~cm})$, 혈관 침습 여부, 주변 구조물 침범 여부, 병리학적 소분류, 최초 원격전이로 확 인되었으나, 이 인자들로 다변량 분석을 시행하였을 때 유의 미한 예측 인자는 병리학적 소분류와 최초 원격전이였다. 병 리학적 소분류 중에서는 광범위 침습형 $(p=0.036)$ 이 나쁜 예 후를 보였다. 휘틀세포암에서는 증례의 수가 적어 통계학적으 로 유의한 예후 예측 인자를 분석하기 어려웠다(Table 4).

\section{고 찰}

갑상선 여포암과 휘틀세포암은 요오드를 섭취하기 어려운 지역에서 더 많이 발생하는 것으로 알려져 있어 요오드 섭취 가 부족하지 않은 우리나라에서는 발생빈도가 더 낮은 것으 로 알려져 있다. ${ }^{8,9)}$

실제로 본원에서는 2000년 1월부터 2020년 12월까지 6003명 의 분화 갑상선암 환자를 치료하였으나 이 중 여포암 환자는 189명(3.1\%), 휘틀세포암 환자는 12명(0.2\%)으로 세계적인 유 병률(여포암: $10 \%$, 휘틀세포암: $3 \%-7 \%$ )에 비해 현저히 낮은 것을 확인할 수 있었다. ${ }^{1,6}$

여포암은 주로 경부 종괴로 발견되나, 최근 건강검진으로 인해 갑상선 초음파의 시행이 늘어나면서 무증상의 영상학적 이상 소견만을 주소로 내원하는 경우가 많아지고 있다. 휘틀 세포암의 경우도 크게 다르지 않으며, 본원의 여포암과 휘틀 세포암 환자들의 주 증상도 대부분 경부 종괴 혹은 영상학적 이상 소견이었다. 다만 골전이가 많은 여포암의 특성때문에 척추, 골반 등의 종괴를 주소로 하는 환자들도 확인할 수 있 었다.

앞서 말한 것처럼, 여포암과 휘틀세포암은 비슷한 방식으로 진단을 하는데 다른 갑상선암과 달리 세침흡인검사로 양성과 악성을 구분하는 것은 불가능하다. ${ }^{24}$ 초음파에서 여포암과 휘 틀세포암 모두 저에코(hypoechoic)에서 고에코(hyperechoic), 이질성 형태(heterogeneous texture), 석회화(calcification) 등의 다양한 소견을 보이기 때문에 초음파 단독으로 악성을 판단하는 것 역시 어려우며, 정확한 진단을 위해서는 수술 검 체를 토대로 한 조직학적 평가가 반드시 필요하다. ${ }^{10,11)}$

수술 전 세침흡인검사 결과는 여포암의 경우 대부분이 미 확정 비정형 세포 혹은 여포상 종양이었고, 휘틀세포암의 경 우는 휘틀세포 종양 혹은 여포상 종양이었다. Bethesda system에 따르면 미확정 비정형 세포의 악성 위험도는 10\%-30\% 정도로 알려져 있고, 반복 세침흡인검사, 분자 검사 $(\mathrm{molecu}-$ lar testing) 혹은 갑상선엽절제술을 권유하고 있으며, 여포상 종양 혹은 휘틀세포 종양의 악성 위험도는 25\%-40\% 정도이
고 분자 검사 혹은 갑상선엽절제술을 권유하고 있다. ${ }^{12)}$ 본원 에서도 이러한 기준에 의해 대부분의 수술이 이루어졌다. 다 만 여포암의 경우 세침흡인검사의 결과가 양성인 비율이 $14 \%$ 정도였는데(Table 2), 이 경우 술자가 수술을 진행한 이유는 대부분 종양의 크기가 $4 \mathrm{~cm}$ 이상으로 컸거나 다발성 종양 때문이었고, 원격전이 부위에서 여포암의 전이가 확인되었으 나 갑상선 세침흡인검사에서는 양성이 나온 경우에도 수술을 진행하였다. 이런 경우를 비추어 볼 때, 세침흡인검사의 결과 가 양성일지라도 영상학적 소견 및 임상적 양상을 종합하여 환자에 대한 평가를 하고 필요하면 수술을 통해 확진을 내리 는 것도 필요하다고 생각된다.

$2017 \mathrm{WHO}$ 분류에서, 갑상선 여포암과 휘틀세포암 둘 다 병리학적 분류상 변경된 부분이 있었다. 먼저 여포암은 이전 까지는 병리학적으로 미세 침습형과 광범위 침습형의 두 군으 로 분류하였는데, 변경된 $2017 \mathrm{WHO}$ 분류에서는 피막 형성 형 혈관 침습형이 추가되어 총 세 군으로 분류하고 그에 따라 예후를 예측하였다. ${ }^{3)}$ 또한 휘틀세포암은 과거 갑상선 여포암 의 아형으로 분류되어 왔으나 휘틀세포암이 특유의 생물학적, 임상적 특징을 지녔고 여포암과는 다른 고유한 유전적 특성 을 가지고 있어 갑상선 여포암의 아형이 아닌 독자적인 그룹 으로 분류하였다. ${ }^{13)}$ 이전 분류에서는 휘틀세포암도 여포암처 럼 미세침습형과 광범위 침습형으로 분류하고 그에 따라 예 후를 예측하였으나, 개정된 $\mathrm{WHO}$ 분류에서는 휘틀세포암에 대한 병리학적 세부 분류에 대해 언급하지 않고 있다. ${ }^{3)}$ 반면 실제 임상에서 많이 사용되는 국립종합암네트워크(National Comprehensive Cancer Network, NCCN) 가이드라인 개정 판(NCCN Guidelines Version 1. 2021)에서는 휘틀세포암의 치료 방침을 결정하는데 여전히 $2017 \mathrm{WHO}$ 에서 개정된 여포 암의 병리학적 분류를 인용하고 있어 향후 병리학적 분류와 임상 치료에 대한 연구와 정리가 필요할 것으로 생각된다. ${ }^{14)}$

$2017 \mathrm{WHO}$ 병리학적 분류를 따랐을 때, 본 연구에서 여포 암은 미세 침습형이 120예(63.5\%), 피막 형성형 혈관 침습형 이 39예(20.6\%), 광범위 침습형이 30예(15.9\%)였다. 이 세 군 의 10 년 무병 생존율을 확인해 보았을 때, 미세 침습형에서 는 $98.3 \%$ 인 반면, 피막 형성형 혈관 침습형과 광범위 침습형 에서는 각각 $87.0 \%, 54.5 \%$ 로 예후가 좋지 않은 것을 확인할 수 있었다. 실제로 예후 인자에 대한 다변량 분석에서도 병리 학적 세부 분류와 진단 시 원격전이가 유의미한 인자로 확인 되었다(Table 4). 휘틀세포암은 미세 침습형이 8예(66.7\%), 피 막 형성형 혈관 침습형이 2예(16.7\%), 광범위 침습형이 2예 (16.7\%)로 확인되었고 이 중 광범위 침습형 1 예에서 다발성 전신전이 및 질병으로 인한 사망 등의 불량한 예후를 확인할 수 있었다. 
모든 분화 갑상선암의 주 치료가 수술적 절제이기 때문에, 여포암과 휘틀세포암 역시 적절한 수술적 절제가 중요하다. ${ }^{14,15)}$ 수술 전 검사만으로는 두 암을 진단할 수가 없기 때문에, 1차 수술로 갑상선엽절제술만을 시행할지, 갑상선전절제술을 시 행할지에 대해서는 의견이 나뉘는데, 일부에서는 갑상선전절 제술을 1차 수술로 진행해야 한다는 의견도 있으나, ${ }^{6}$ 분화 갑 상선암에 대한 수술이 점점 더 보존적(conservative)인 방향 으로 권유되고 있어 1차 수술로는 갑상선엽절제술을 시행하는 것이 선호된다. 다만 여포암과 휘틀세포암 모두 이전의 연구들 에서 공통적으로 종양의 크기가 클수록 $(4 \mathrm{~cm}$ 이상) 악성의 위 험도가 높아진다는 보고들이 있어 ${ }^{16,17)}$ 크기가 큰 종양은 1차 수술로 갑상선 전 절제술을 시행하는 것도 고려해 볼 수 있 을 것이다. 또한 영상학적으로 침습적이거나 진단 시 경부 림 프절 전이와 같은 국소전이 및 원격전이가 확인되었을 시에도 갑상선전절제술을 시행할 수 있다.

본원의 여포암 환자 중 1차 치료로 갑상선전절제술을 시행 한 경우를 의무기록을 통해 조사해본 결과 최초 전신 전이가 있거나, 갑상선 양측에 종양이 있거나, 종양의 크기가 크거나, 수술 중 술자의 판단에 따른 경우인 것이 확인되었고, 휘틀 세포암의 경우에도 최초 전신전이가 있던 경우나 종양의 크 기가 컸던 경우에 1차 치료로 갑상선전절제술을 시행하였다.

진단적 엽절제술 후 조직 병리 검사 결과에 따라 2차 치료 가 결정되는데, 앞서 언급했듯이 $2021 \mathrm{NCCN}$ 가이드라인에 서는 휘틀세포암도 여포암과 같은 병리학적 분류를 사용하고 있고 치료의 흐름도 크게 다르지 않다. 미세 침습형 혹은 4개 미만의 혈관 침범이 있는 피막 형성형 혈관 침습형(encapsulated angioinvasive with $<4$ vessels)인 경우 경과 관찰이나 갑상선완전절제술 중 선택할 수 있으며 광범위 침습형이나 피막 형성형 혈관 침습형 중 4 개 이상의 혈관 침범이 있는 경 우(encapsulated angioinvasive with $\geq 4$ vessels)는 갑상선 완결절제술을 시행한다. 본원의 경우 미세 침습형에서 갑상선 엽절제술 44예, 전절제술 76예를, 피막 형성형 혈관 침습형에 서 갑상선엽절제술 11 예, 전절제술을 28예를, 광범위 침습형 에서 갑상선엽절제술 3 예, 전절제술을 27 예 시행하였는데, 병 리 결과가 나쁠수록 전절제술을 더 시행함으로써 이러한 가 이드라인과 부합하는 치료를 시행하였다. 휘틀세포암 12 예 중 에서는 미세 침습형에서 갑상선엽절제술 4예, 전절제술 4예를, 피막 형성형 혈관 침습형에서 갑상선엽절제술 1 예, 전절제술 1 예를, 광범위 침습형에서는 갑상선전절제술만 2예 시행하였 다. 광범위 침습형 중 사망한 1 예를 제외하고 모두 좋은 예후 를 보이고 있고, 비록 최근의 연구들에서 휘틀세포암과 여포 암과의 예후에 차이가 없다는 보고들이 나오고 있지만, ${ }^{18)}$ 이 전 연구들에서는 다른 분화 갑상선암에 비해 좋지 않은 예후
를 보였기에 ${ }^{5)}$ 추후 정기적인 장기 추적 관찰을 통해 예후를 관찰할 예정이다. 또한 본원의 연구는 증례 수가 적은 관계로, 휘틀세포암의 병리학적 분류에 따른 수술 방법과 그 예후에 대한 다기관 협조를 통한 대규모 연구가 필요할 것으로 생각 된다.

여포암에서 수술 후 방사성 요오드 치료의 적응증에 대해 서는 각 학회 혹은 협회마다 조금씩 차이가 있으나, 대부분 혈관 침습이 있거나 크기가 $4 \mathrm{~cm}$ 이상이거나 고령 등의 위험 인자가 있을 때 방사성 요오드 치료를 권유하고 있다. ${ }^{19)}$ 휘틀 세포암에서 어떤 연구들은 방사성 요오드 치료가 장기간 생 존율에 영향을 미치지 않는다고 보고하였으나, ${ }^{20)}$ 다른 연구 들에서는 방사성 요오드 치료를 받은 환자들에서 5년, 10년 생존율이 향상되었다고 보고하였다. ${ }^{21)} 2021 \mathrm{NCCN}$ 가이드라 인에서도 상황에 따라 여포암과 휘틀세포암에서 방사성 요오 드 치료를 권유하고 있는데, 종양의 크기가 $2-4 \mathrm{~cm}$ 이거나, 심 하지 않은 혈관 침습, 경부 림프절 전이가 있는 경우, 수술 후 티로글로불린 수치가 5-10 ng/mL 미만인 경우, 현미경적으 로 양성 절제연(positive margin)인 경우에는 환자의 특성에 따라 방사성 요오드 치료를 고려해 볼 수 있고, 종양의 크기 가 $4 \mathrm{~cm}$ 를 초과하거나 육안적 갑상선 외 침범, 광범위한 혈 관 침습, 수술 후 티로글로불린 수치가 5-10 ng/mL 초과인 경우, 5 개 초과의 림프절 전이에서는 방사성 요오드 치료를 권유하고 있다. 본원의 경우 여포암 환자에서는 갑상선전절제 술을 시행한 131예 중 대부분인 126예에서, 휘틀세포암 환자 에서는 갑상선전절제술을 시행한 7예 모두에서 방사성 요오 드 치료를 시행하였고 대부분이 좋은 예후를 보였다.

갑상선 여포암과 휘틀세포암의 수술 후 추적 관찰 방법은 차이는 없으며, 초기에는 매 6-12개월마다 티로글로불린 및 안티티로글로불린 항체 수치를 확인하는 것이 바람직하며, 재발 고위험군에서는 더 잦은 간격으로 검사를 하는 것이 적 합하다. 재발 저위험군, 중간위험군에서는 검사 간격을 매 12-24개월로 늘릴 수 있고, 고위험군에서는 몇 년간은 6-12 개월로 유지하는 것이 좋다. ${ }^{14)}$

경부 초음파 역시 수술 후 매 6-12개월 간격으로 시행하며, 갑상선 수술부(thyroid bed), 중심 경부 및 측경부 림프절을 평가한다. 이후에 점차적으로 각 환자의 재발 위험도나 치료 에 대한 반응을 고려하여 검사 간격을 늘리는 것이 좋다. ${ }^{14,22)}$

또한 2015 미국 갑상선학회 갑상선 결절 및 암 진료권고안 에 의하면 고위험군의 분화 갑상선 암 환자, 혹은 티로글로불 린 수치는 상승했으나 방사성 요오드 스캔에서 음성인 환자 에서 fluorodeoxyglucose (FDG) PET검사를 권고하고 있으 며, 여러 연구들에서 방사성 요오드 스캔에서 위음성율이 높 은 휘틀세포암에서 FDG PET이 높은 민감도를 보인다는 보 
고가 있어 $\mathrm{FDG} \mathrm{PET}$ 을 고위험군의 휘틀세포암에서 일차 검 사로 고려해 볼 수 있다. ${ }^{15,23,24)}$

이 외에 갑상선 여포암이 주로 폐, 다음으로 빼로 전이가 흔하기 때문에, ${ }^{22)}$ 티로글로불린 수치가 증가하였으나 경부 영 상에서 특이소견이 없는 고위험군 환자에서는 폐, 뼈 등의 장 기로의 전이 가능성을 배제할 수 없으므로 흥부 CT 혹은 뼈 스캔 등을 시행하는 것이 바람직할 것으로 생각된다. ${ }^{14)}$

갑상선 여포암의 10년 생존율은 연구마다 차이가 있지만, 95\%-98\% 정도이다. 최근 $2017 \mathrm{WHO}$ 분류를 반영한 O’Neil 의 연구에서는 갑상선 여포암의 40 개월 무병 생존율은 미세 침습형이 $97 \%$, 피막 형성형 혈관 침습형이 $81 \%$, 광범위 침습 형이 $46 \%$ 로 나타났으며, 본원의 연구에서도 40 개월 무병 생 존율은 미세 침습형이 $98.3 \%$, 피막 형성형 혈관 침습형이 $87.0 \%$, 광범위 침습형이 $59.4 \%$ 로 큰 차이가 없음을 확인하 였다. ${ }^{25)}$

휘틀세포암의 예후는 재발률 7\%-53\%, 10년 생존율 45\%$80 \%$ 등으로 다양하게 보고되고 있으나 일반적으로 다른 갑 상선 분화암에 비해 비교적 불량한 경과를 보인다고 알려져 왔다. ${ }^{523)}$ 하지만 이는 과거 보고들에서 휘틀세포암이 고령에 호발하는 특성이 있는데 연령을 보정하지 않아 발생한 오류 인 것으로 생각되어지며, ${ }^{5,26}$ 최근 발표된 자료들에 의하면 동 일한 조건의 환자들에서 휘틀세포암과 갑상선 여포암의 예후 에 큰 차이가 없다고 한다. ${ }^{5)}$ 본 연구의 경우 휘틀세포암의 증 례 수가 적어 예후 차이에 대하여 정확한 비교는 어렵지만 여 포암과 휘틀세포암 모두 미세침습형과 피막 형성혈 혈관 침 습형은 비교적 좋은 예후를, 광범위 침습형에서 좋지 않은 예 후를 보여주었고, 최초 전신전이가 있는 환자에서 좋지 않은 예후를 확인할 수 있었다. 많은 증례의 정확한 분석을 위해 서는 다기관 연구가 필요할 것으로 생각된다.

결론적으로, 저자들은 갑상선 여포암과 휘틀세포암의 임상 양상과 치료, 예후, 예후인자와 각각에 대한 비교 결과를 제 시하였다. 본 연구가 비교적 드문 암인 여포암과 휘틀세포암 의 진단과 치료에 도움이 될 것으로 생각한다.

\section{Acknowledgments}

None.

\section{Author Contribution}

Conceptualization: Ik Joon Choi, Byeong-Cheol Lee, Jung Min Ahn, Myung-Chul Lee. Data curation: Brian Kim, Byeong-Cheol Lee. Formal analysis: Jung Jun Kim, Brian Kim, Jung Min Ahn, Joon Seog Kong, Myung-Chul Lee. Investigation: Ik Joon Choi. Methodology: Joon Seog Kong. Project administration: Jung Min Ahn. Visualization: Byeong-Cheol Lee, Joon Seog Kong. Writingoriginal draft: Jung Jun Kim. Writing — review \& editing: Jung Jun Kim.

\section{ORCID}

Myung-Chul Lee https://orcid.org/0000-0002-2574-4976

\section{REFERENCES}

1) Varadarajan VV, Pace EK, Patel V, Sawhney R, Amdur RJ, Dziegielewski PT. Follicular thyroid carcinoma metastasis to the facial skeleton: A systematic review. BMC Cancer 2017;17(1):225.

2) Mo JA, Lee GH, Lee BC, Lee MC, Jung MS, Cho PS, et al. Clinical menifestation and anaylsis of thyroid follicular carcinoma. Korean J Otorhinolaryngol-Head Neck Surg 2010;53(1):30-6.

3) Kakudo K, Bychkov A, Bai Y, Li Y, Liu Z, Jung CK. The new 4th edition World Health Organization classification for thyroid tumors, Asian perspectives. Pathol Int 2018;68(12):641-64.

4) Kim JJ, Kang JY, Choi IJ, Lee MC. Hurthle cell carcinoma of the thyroid: A case report of 12 cases. Korean J Otorhinolaryngol-Head Neck Surg 2020;63(12):615-9.

5) Lopez-Penabad L, Chiu AC, Hoff AO, Schultz P, Gaztambide S, Ordoñez NG, et al. Prognostic factors in patients with Hürthle cell neoplasms of the thyroid. Cancer 2003;97(5):1186-94.

6) Mills SC, Haq M, Smellie WJ, Harmer C. Hürthle cell carcinoma of the thyroid: Retrospective review of 62 patients treated at the Royal Marsden Hospital between 1946 and 2003. Eur J Surg Oncol 2009;35(3):230-4.

7) Sugino K, Kameyama K, Ito K, Nagahama M, Kitagawa W, Shibuya H, et al. Does Hürthle cell carcinoma of the thyroid have a poorer prognosis than ordinary follicular thyroid carcinoma? Ann Surg Oncol 2013;20(9):2944-50.

8) Lee JD, Lee SH, Choi SY, Nam KH, Chung WY, Soh EY, et al. Hurthle cell carcinoma of the thyroid gland: Clinicopathologic features and treatment outcome compared with pure follicular thyroid carcinoma. J Korean Surg Soc 2008;74(2):91-7.

9) Barnabei A, Ferretti E, Baldelli R, Procaccini A, Spriano G, Appetecchia M. Hurthle cell tumours of the thyroid. Personal experience and review of the literature. Acta Otorhinolaryngol Ital 2009;29(6):305-11.

10) Maizlin ZV, Wiseman SM, Vora P, Kirby JM, Mason AC, Filipenko D, et al. Hurthle cell neoplasms of the thyroid: Sonographic appearance and histologic characteristics. J Ultrasound Med 2008; 27(5):751-7.

11) Zhang JZ, Hu B. Sonographic features of thyroid follicular carcinoma in comparison with thyroid follicular adenoma. J Ultrasound Med 2014;33(2):221-7.

12) Cibas ES, Ali SZ. The 2017 Bethesda system for reporting thyroid cytopathology. Thyroid 2017;27(11):1341-6.

13) Erickson LA, Jin L, Goellner JR, Lohse C, Pankratz VS, Zukerberg LR, et al. Pathologic features, proliferative activity, and cyclin D1 expression in Hurthle cell neoplasms of the thyroid. Mod Pathol 2000;13(2):186-92.

14) National Comprehensive Cancer Network. Clinical practice guidelines in oncology-thyroid carcinoma. version 1. 2021. [serial online] 2021 June [cited 2021 Jun 28] Available from: URL: https:// www.ncen.org/professionals/physician_gls/pdf/thyroid.pdf.

15) Haugen BR, Alexander EK, Bible KC, Doherty GM, Mandel SJ, Nikiforov YE, et al. 2015 American Thyroid Association management guidelines for adult patients with thyroid nodules and differentiated thyroid cancer: The American Thyroid Association guidelines task force on thyroid nodules and differentiated thyroid cancer. Thyroid 2016;26(1):1-133.

16) Ahmadi S, Stang M, Jiang XS, Sosa JA. Hürthle cell carcinoma: Current perspectives. Onco Targets Ther 2016;9:6873-84.

17) Paramo JC, Mesko T. Age, tumor size, and in-office ultrasonography are predictive parameters of malignancy in follicular neoplasms of the thyroid. Endocr Pract 2008;14(4):447-51. 
18) Bhattacharyya N. Survival and prognosis in Hürthle cell carcinoma of the thyroid gland. Arch Otolaryngol Head Neck Surg 2003;129(2): 207-10.

19) Staubitz JI, Musholt PB, Musholt TJ. The surgical dilemma of primary surgery for follicular thyroid neoplasms. Best Pract Res Clin Endocrinol Metab 2019;33(4):101292.

20) Goffredo P, Roman SA, Sosa JA. Hurthle cell carcinoma: A population-level analysis of 3311 patients. Cancer 2013;119(3):50411.

21) Jillard CL, Youngwirth L, Scheri RP, Roman S, Sosa JA. Radioactive iodine treatment is associated with improved survival for patients with Hürthle cell carcinoma. Thyroid 2016;26(7):959-64.

22) McHenry CR, Phitayakorn R. Follicular adenoma and carcinoma of the thyroid gland. Oncologist 2011;16(5):585-93.
23) Chindris AM, Casler JD, Bernet VJ, Rivera M, Thomas C, Kachergus JM, et al. Clinical and molecular features of Hürthle cell carcinoma of the thyroid. J Clin Endocrinol Metab 2015;100(1):5562.

24) Pryma DA, Schöder H, Gönen M, Robbins RJ, Larson SM, Yeung HW. Diagnostic accuracy and prognostic value of 18F-FDG PET in Hürthle cell thyroid cancer patients. J Nucl Med 2006;47(8):1260-6.

25) Badulescu CI, Piciu D, Apostu D, Badan M, Piciu A. Follicular thyroid carcinoma - clinical and diagnostic findings in a 20-year follow up study. Acta Endocrinol (Buchar) 2020;16(2):170-7.

26) Haigh PI, Urbach DR. The treatment and prognosis of Hürthle cell follicular thyroid carcinoma compared with its non-Hürthle cell counterpart. Surgery 2005;138(6):1152-7; discussion 1157-8. 